\title{
Hibiscus rosa-sinensis leaf extract as coagulant aid in leachate treatment
}

\author{
Nik Azimatolakma Awang $\cdot$ Hamidi Abdul Aziz
}

Received: 5 March 2012 / Accepted: 27 June 2012/Published online: 11 July 2012

(C) The Author(s) 2012. This article is published with open access at Springerlink.com

\begin{abstract}
Hibiscus rosa-sinensis is a biodegradable material that has remained untested for flocculating properties. The objective of this study is to examine the efficiency of coagulation-flocculation processes for the removal of color, iron $\left(\mathrm{Fe}^{3+}\right)$, suspended solids, turbidity and ammonia nitrogen $\left(\mathrm{NH}_{3}-\mathrm{N}\right)$, from landfill leachate using $4,000 \mathrm{mg} / \mathrm{L}$ alum in conjunction with $H$. rosa-sinensis leaf extract (HBaqs). Hydroxyl $(\mathrm{O}-\mathrm{H})$ and (carboxyl) $\mathrm{C}=\mathrm{O}$ functional groups along the HBaqs chain help to indulge flocculating efficiency of HBaqs via bridging. The experiments confirm the positive coagulation properties of HBaqs. The $\mathrm{Fe}^{3+}$ removal rate using $4,000 \mathrm{mg} / \mathrm{L}$ alum as sole coagulant was approximately $60 \%$, and increased to $100 \%$ when $4,000 \mathrm{mg} / \mathrm{L}$ alum was mixed with $500 \mathrm{mg} / \mathrm{L}$ HBaqs. By mixing, 4,000 mg/L alum with $100-500 \mathrm{mg} / \mathrm{L}$ HBaqs, $72 \%$ of SS was removed as compared with only $45 \%$ reduction using $4,000 \mathrm{mg} / \mathrm{L}$ alum as sole coagulant.
\end{abstract}

Keywords Alum · Coagulant aid ·

Hibiscus rosa-sinensis · Leachate

\section{Introduction}

Quite a number of researchers (e.g., Aziz et al. 2007; Cheng and Chi 2002, Cheng et al. 2004; Duan and Gregory 2003; Zouboulis et al. 2004) have focused on the coagulation-flocculation process using chemical-based coagulants, such as alum and ferric salts. Reported studies have mainly focused on the application of alum or ferric salts to

N. A. Awang - H. A. Aziz $(\bowtie)$

School of Civil Engineering, Universiti Sains Malaysia,

14300 Nibong Tebal, Penang, Malaysia

e-mail: cehamidi@eng.usm.my treat leachate and synthetic wastewater consisting of humic acid, kaolin, dyes, phosphate, and magnesium which contribute to biochemical oxygen demand $\left(\mathrm{BOD}_{5}\right)$, chemical oxygen demand (COD), color, turbidity and suspended solids (SS).

However, there is not much published information on the application of natural coagulants for wastewater purification. The existing literature (e.g., Okuda et al. 2001a, b; Šćiban et al. 2009; Anastasakis et al. 2009; Beltrán-Heredia and Sánchez-Martín 2009) have mostly examined the removals of SS and turbidity in synthetic water (as elucidated above), streams or river water sources, municipal effluent, and dye wastewater. However, no study has been conducted for the treatment of landfill leachate.

Several studies have used synthetic polyelectrolytes as coagulant aids in a dual coagulant system (Kam and Gregory 2001; Zouboulis et al. 2004; Aguilar et al. 2005; Lee and Westerhoff 2006). However, few experiments using a natural coagulant as a coagulant aid have been documented. Hence, the level of efficiency of a new natural coagulant as a coagulant aid is difficult to compare directly with results gained from other published works. In general, in a dual coagulant system, the inorganic coagulant promotes the destabilization of colloids mainly through charge neutralization. Subsequently, a polymer or polyelectrolyte acts as a bridging agent in promoting the formation of greater flocs that settle more efficiently, ultimately resulting in higher removal rates (Zouboulis et al. 2004).

The importance of this study lies in ascertaining the efficiency of a new natural coagulant in the treatment of wastewater with the aspiration that, using a locally available material, the treatment cost could be reduced. This study was aimed to: (1) extract a coagulant from the leaves of Hibiscus rosa-sinensis, and examine its chemical characteristics based on isoelectric point (IEP), molecular 
weight, and functional groups using Fourier transform infrared (FTIR), (2) examine the efficiency of coagulationflocculation processes for the removal of color, iron $\left(\mathrm{Fe}^{3+}\right)$, suspended solids, turbidity and ammonia nitrogen $\left(\mathrm{NH}_{3}-\mathrm{N}\right)$, from landfill leachate using $4,000 \mathrm{mg} / \mathrm{L}$ alum in conjunction with $H$. rosa-sinensis leaf extract (HBaqs).

\section{Materials and methods}

This research includes: leachate sampling and characterization, HBaqs preparation, HBaqs characterization (IEP, molecular weight, FTIR spectra), coagulation experiments, and analytical determinations.

Leachate sampling and characterization

The leachate sample was collected from the Pulau Burung Landfill (PBLS) situated in Penang, Malaysia. PBLS is a semi-aerobic landfill site, and is one of only three sites of its kind in Malaysia. PBLS produces a dark black-green colored liquid that can be classified as a stable leachate with high concentrations of COD and ammonium and a low BOD/COD ratio (Ghafari et al. 2010). The characteristics of the leachate influent taken from the active detention pond, Leachate Pond 1, of the PBLS treatment plant are listed in Table 1.

\section{HBaqs preparation}

The collected fresh leaves of $H$. rosa-sinensis were repeatedly washed with water to remove dust and soluble impurities. Then, $X_{1} \mathrm{~g}$ of the green leaves was placed in a beaker containing $Y_{1} \mathrm{~L}$ of distilled water. The mixture was then blended using a domestic blender operated at a high speed to extract the active ingredient of the $H$. rosa-

Table 1 Characteristics of raw leachate from PBLS

\begin{tabular}{lllll}
\hline Parameter & Minimum & Maximum & Average $^{\mathrm{a}}$ & Standard $^{\mathrm{b}}$ \\
\hline $\mathrm{pH}$ & 8.24 & 8.82 & 8.65 & $6.0-9.0$ \\
$\mathrm{SS}$ & 165 & 211 & 189 & 50 \\
$\mathrm{Fe}^{3+}$ & 2.22 & 5.23 & 4.2 & 5 \\
$\mathrm{NH}_{3}-\mathrm{N}$ & 1,840 & 2,465 & 2,125 & 5 \\
$\mathrm{COD}$ & 2,873 & 3,360 & 3,170 & 400 \\
Turbidity & 275 & 325 & 303 & - \\
Color & 4,780 & 5,120 & 4,950 & 100 \\
\hline
\end{tabular}

a Average of 14 samples taken from October 2008 till November 2009

b The standard requirements of the Environmental Quality Act 1974 (2010) and the limits set down by the Environmental Quality (control of pollution from solid waste transfer station and landfill) Regulation 2009, Malaysia sinensis. The suspension was filtered into a beaker. The leaf dregs were dried in an oven for $48 \mathrm{~h}$ at $105^{\circ} \mathrm{C}$. Meanwhile, the filtrate stock solutions were stirred using a magnetic stirrer for $30 \mathrm{~min}$ at room temperature. The dry leaf dregs were weighed, and the amount was defined as $X_{2}$. The pure concentration, $M_{1}$, of the dissolved filtrate stock solution, HBaqs, was calculated as follows:

$M_{1}=\frac{X_{1}-X_{2}}{Y_{1}}$

HBaqs was used for the coagulation experiments either immediately or after storage at $4{ }^{\circ} \mathrm{C}$.

HBaqs characterization: isoelectric point

The surface charge of HBaqs was evaluated by determining the electrophoretic mobility of the suspended particles with Malvern Zetasizer Nano ZS. Measurements were taken at $25{ }^{\circ} \mathrm{C}$ with distilled water as the dispersal medium. The IEP for HBaqs was determined by the titration of $10 \mathrm{ml}$ HBaqs with $0.25 \mathrm{M} \mathrm{HCl}$ or $0.25 \mathrm{M} \mathrm{NaOH}$ from $\mathrm{pH} 12$ to 3 .

HBaqs characterization: molecular weight

The molecular weight of HBaqs was determined using Malvern Zetasizer Nano ZS. Four different sample concentrations were prepared by diluting a high concentration of HBaqs with toluene as the solvent. Prepared sample was filtered before use. Data collection and calculations were managed using the Molecular Weight function in the DTS software for the Zetasizer Nano system, which compiles the static intensity measurements and generates a standard Debye plot.

HBaqs characterization: FTIR spectra

FTIR Perkin Elmer was used to investigate the structure of HBaqs and to analyze their functional groups.

\section{Coagulation experiments}

The aluminum sulfate (alum), $\mathrm{Al}_{2}\left(\mathrm{SO}_{4}\right)_{3} \cdot 18 \mathrm{H}_{2} \mathrm{O}$, used in this study was in powder form, and supplied by Merck, Germany. The conventional jar test with a six-unit multiple stirrer system was used. Six beakers with $1,000-\mathrm{mL}$ volume were filled with $500 \mathrm{~mL}$ of leachate, $400 \mathrm{mg} / \mathrm{L}$ alum was added into each beaker, and $\mathrm{pH}$ was fixed at 6 . The leachate was rapidly stirred at $200 \mathrm{rpm}$ for $30 \mathrm{~min}$. 100, 500, 1,000, 2,000 and 4,000 $\mathrm{mg} / \mathrm{L}$ of HBaqs were added into five beakers after the rapid mixing. One beaker was left as control (without addition of HBaqs). For the next 20 min, the mixture was stirred at $30 \mathrm{rpm}$. It was then allowed to settle for a period of $30 \mathrm{~min}$. 
Analytical determinations

Supernatant samples were withdrawn from $2 \mathrm{~cm}$ below the liquid level, and analyzed for $\mathrm{SS}, \mathrm{Fe}^{3+}, \mathrm{NH}_{3}-\mathrm{N}$, turbidity and color in accordance with the standard method for the examination of water and wastewater (APHA, AWWA, WEF 2005). A DR/2500 Hach spectrophotometer was employed to determine $\mathrm{SS}, \mathrm{Fe}^{3+}, \mathrm{NH}_{3}-\mathrm{N}$. SS determination was conducted using the photometric method, Method 8006. $\mathrm{Fe}^{3+}$ was determined in accordance with FerrorVer ${ }^{\circledR}$ method (Method 8008). $\mathrm{NH}_{3}-\mathrm{N}$ was measured based on Nessler method (Method 8038), color was measured as true color by APHA platinum-cobalt (PtCo) standard method, Method 8025. Turbidity was determined by attenuate radiation method (direct reading), Method 8237 with DR2010 spectrophotometer. The removal efficiency for parameter analysis was calculated using Eq. (2):

$\operatorname{Removal}(\%)=\left[\frac{\left(C_{\mathrm{i}}-C_{\mathrm{f}}\right)}{C_{\mathrm{i}}}\right] 100$

where $C_{\mathrm{i}}$ and $C_{\mathrm{f}}$ are the initial and final concentrations of the sample, respectively.

\section{Results}

Characteristic of HBaqs

Figure 1 illustrates the zeta potential of HBaqs in conjunction with $\mathrm{pH}$. At $\mathrm{pH} 4$ (IEP), surface charge of HBaqs was absolutely neutral while it turned positive at $\mathrm{pH}$ below 4 and negative at $\mathrm{pH}$ beyond 4 . Under these conditions, it can be said that HBaqs were anionic coagulants, and the main mechanism governing the aggregation of the constituents was bridging. While, from the Debye plot, the molecular weight of HBaqs is $183 \mathrm{kDa}$. Based on Zhang et al. (2010) and Beltrán-Heredia and Sánchez-Martín (2009) definition, polymer with molecular weight over $100 \mathrm{kDa}$ are high molecular weight, it can be concluded that HBaqs could be classified as a high molecular-weight anionic polymer.

Analysis of FTIR spectra to determine the main functional groups of HBaqs was performed based on various references available in literature (Prasertsan et al. 2006; Hanafiah et al. 2007; Li et al. 2008). Zhang et al. (2010) claimed that carboxyl $(\mathrm{C}=\mathrm{O})$, hydroxyl $(\mathrm{O}-\mathrm{H})$ and amino or amide $\left(-\mathrm{NH}_{2}\right)$ groups as well as hydrogen bonding, which were the preferred groups for the flocculation process exist in FTIR spectrum of TJ-F1. Hence, results from Table 2 showed that only $\mathrm{O}-\mathrm{H}$ and $\mathrm{C}=\mathrm{O}$ groups were involved during coagulation-flocculation process for HBaqs. Others functional groups, $\mathrm{N}-\mathrm{H}, \mathrm{C}-\mathrm{H}$ and $\mathrm{C}-\mathrm{O}$ did not contribute much to coagulation-flocculation process.

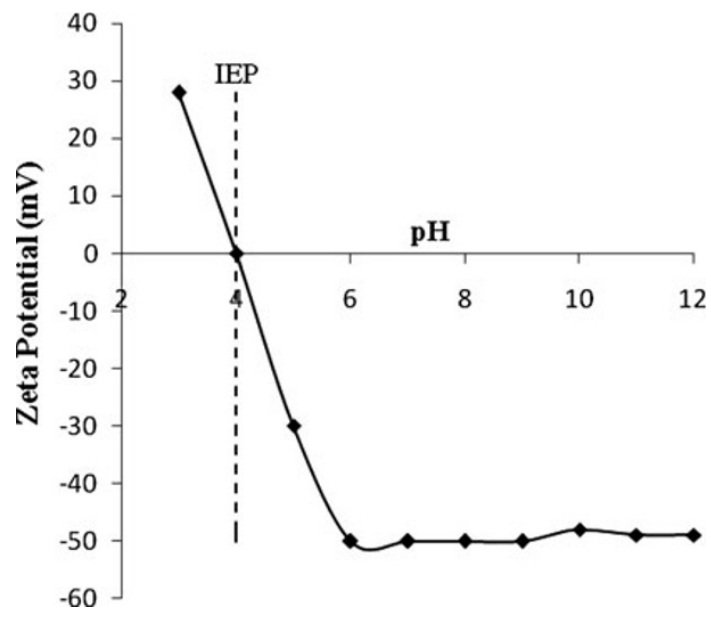

Fig. 1 Effect of $\mathrm{pH}$ value on the zeta potential values of HBaqs $(2,000 \mathrm{mg} / \mathrm{L})$

Thus, HBaqs shows an anionic character at high $\mathrm{pH}$ due to ionization of $\mathrm{C}=\mathrm{O}$ groups. The dissociated carboxyl $\left(-\mathrm{C}=\mathrm{O}^{-}\right)$groups will serves as ion bridge or binding sites for divalent metal cations $\left(\mathrm{Ca}^{2+}, \mathrm{Mg}^{2+}\right.$, etc. $)$ at the particle surface of wastewater to induce the coagulation activity.

Removal rate

The $\mathrm{pH}$ is an important variable in the decolorization process. Increasing the HBaqs dose did not significantly affect the color removal; rather, it resulted in a linearly constant removal pattern (Fig. 2). In fact, 4,000 mg/L alum combined with $500 \mathrm{mg} / \mathrm{L}$ HBaqs only managed to remove $61 \%$ color as compared to $69 \%$ by $7,000 \mathrm{mg} / \mathrm{L}$ alum alone.

The HBaqs additives enhanced $\mathrm{Fe}^{3+}$ removal more than when alum was used alone (Fig. 3). The $\mathrm{Fe}^{3+}$ removal rate using 4,000 $\mathrm{mg} / \mathrm{L}$ alum as the sole coagulant was approximately $60 \%$, and increased to $100 \%$ when $500 \mathrm{mg} / \mathrm{L}$ HBaqs was mixed with 4,000 mg/L alum. $\mathrm{Fe}^{3+}$ most likely acted as a bridge between the anionic groups on the HBaqs and the negative sites on the surfaces, which is consistent with the study of Henderson and Wheatley (1987), where the flocculation by anionic polyacrylamide was adversely affected by the presence of multivalent metal ions, such as $\mathrm{Fe}^{3+}$. Metal ion like divalent metal cation, $\mathrm{Fe}^{3+}$ had high affinity for attachment on anionic polymer $\left(-\mathrm{C}=\mathrm{O}^{-}\right)$due to its own charge. When metal ions agglomerate with $-\mathrm{C}=\mathrm{O}^{-}$ on polymer chain, the ionic strength around anionic polymer will subsequently decrease. This induces the polymer to bridge long distance.

Strong and high correlation between turbidity and SS was observed, as presented in Fig. 4, because the sampling was made at a single particular site. The combination of $100-500 \mathrm{mg} / \mathrm{L}$ HBaqs and 4,000 mg/L alum managed to 
Table 2 Main functional groups on HBaqs backbone

\begin{tabular}{ll}
\hline Vibration type & $\begin{array}{l}\text { Wavenumber } \\
\left(\mathrm{cm}^{-1}\right)\end{array}$ \\
\hline $\begin{array}{l}\text { Hydroxyl and amines (O-H and N-H } \\
\text { stretching) }\end{array}$ & 3,446 \\
Alkanes (C-H stretching) & 2,929 \\
Carboxyl (C=O stretching) & $1,429-1,639$ \\
Methoxyl (C-O stretching of carboxylic acids) & 1,319 \\
Methoxyl (C-O stretching of alcoholic groups) & $1,053-1,159$ \\
\hline
\end{tabular}

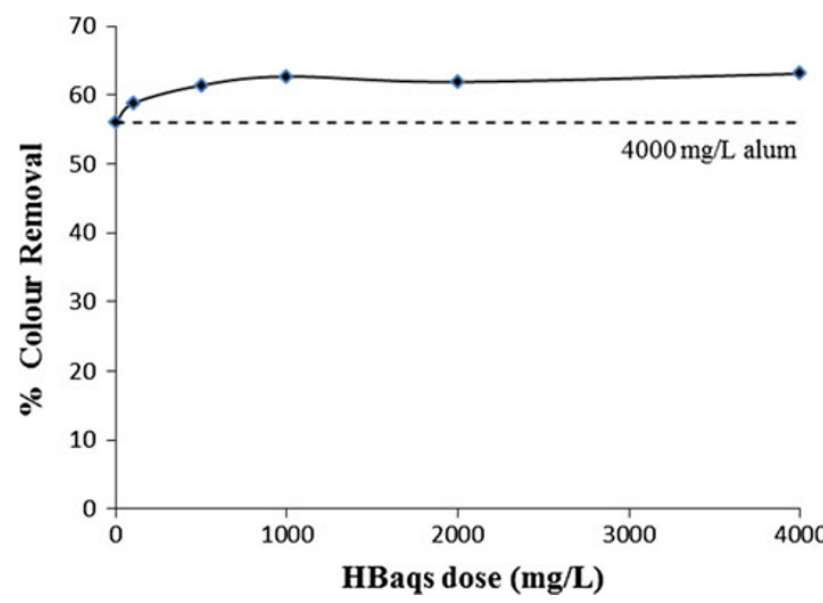

Fig. 2 Effect of HBaqs dose on color of leachate after the addition of $4,000 \mathrm{mg} / \mathrm{L}$ alum

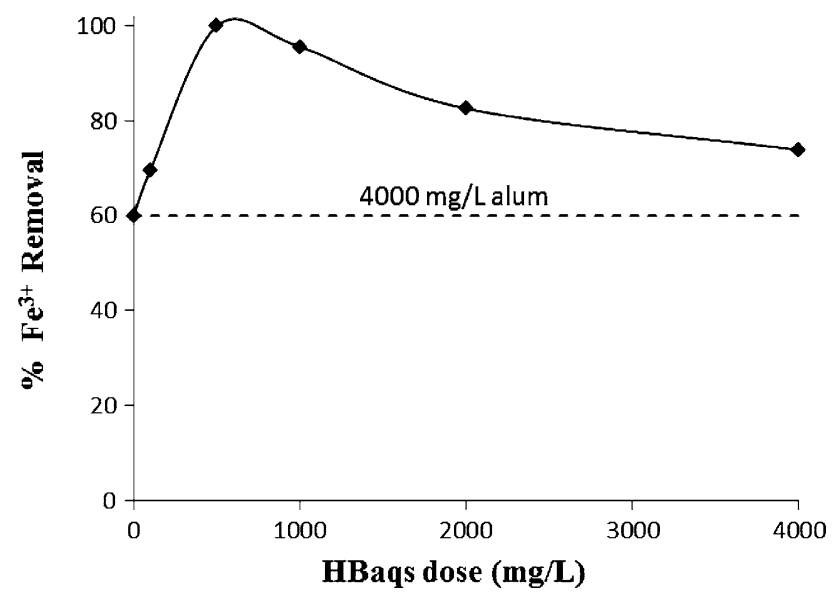

Fig. 3 Effect of HBaqs dose on $\mathrm{Fe}^{3+}$ of leachate after the addition of $4,000 \mathrm{mg} / \mathrm{L}$ alum

surpass $4,000 \mathrm{mg} / \mathrm{L}$ alum alone by removing approximately 72 and $60 \%$ of SS and turbidity, respectively, which only 45 and $36 \%$ were removed by the sole alum coagulant, respectively. In particular, removal of SS and turbidity continually decreased as the HBaqs dose was

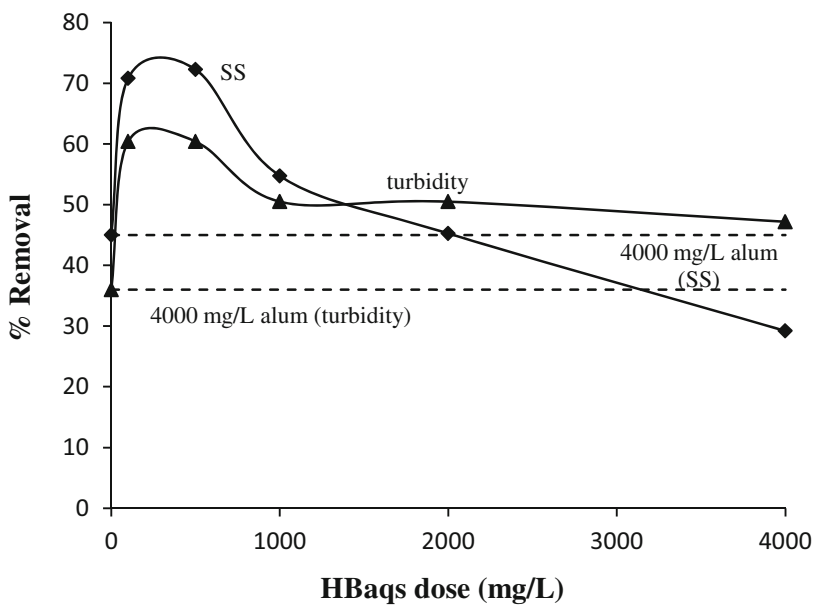

Fig. 4 Effect of HBaqs dose on SS and turbidity of leachate after addition of $4,000 \mathrm{mg} / \mathrm{L}$ alum

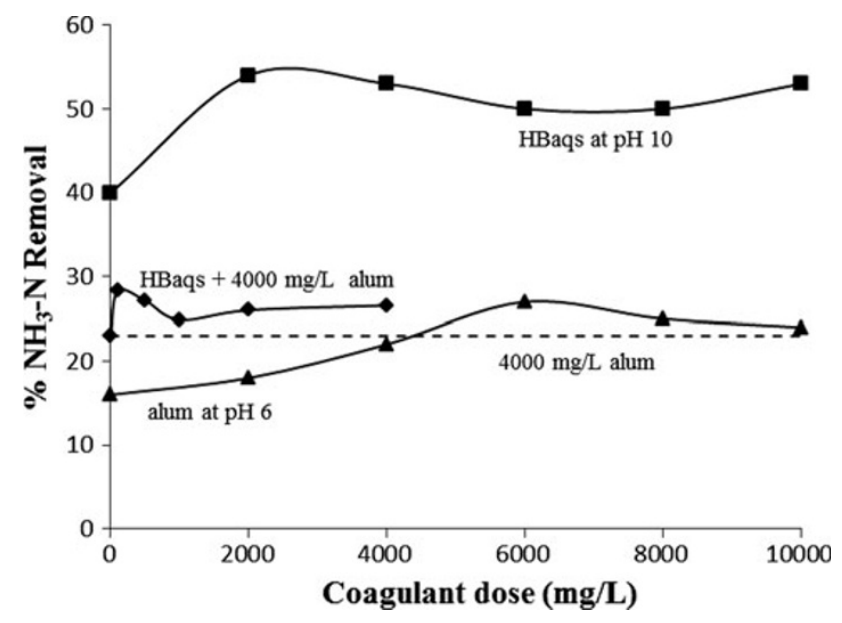

Fig. 5 Effect of coagulant dose on $\mathrm{NH}_{3}-\mathrm{N}$ removal from leachate

increased to over $1,000 \mathrm{mg} / \mathrm{L}$. This overdosing resulted in the saturation of the HBaqs bridge sites, which occupied the surface of the particle for the attachment of segments or interparticle bridges, and caused restabilization of the destabilized particles (Jarvis et al. 2004; Aziz et al. 2000, 2007; Ghafari et al. 2010), and enmeshment (Jarvis et al. 2005). In the meantime, the adsorbed layers could have also caused steric repulsion (Ersoy 2005).

The highest removal rate for $\mathrm{NH}_{3}-\mathrm{N}$ by $4,000 \mathrm{mg} / \mathrm{L}$ alum combined with HBaqs was $28 \%$ (Fig. 5), $3 \%$ above the removal using $4,000 \mathrm{mg} / \mathrm{L}$ as sole coagulant. However, further experiments showed that HBaqs could effectively remove $\mathrm{NH}_{3}-\mathrm{N}$ in leachate when use as sole coagulant at $\mathrm{pH}$ 10. The latter was in agreement with the previous findings using other natural coagulants, such as from chestnut and acorn (Šćiban et al. 2009) and Moringa oleifera (Okuda et al. 2001b). A dosage of 2,000 mg/L HBaqs exhibited the highest $\mathrm{NH}_{3}-\mathrm{N}$ removal rate of $54 \%$. 
Result also showed that $\mathrm{NH}_{3}-\mathrm{N}$ removal was the lowest when alum was used as sole coagulant.

\section{Discussion}

The general mechanisms that typically take place in coagulation-flocculation are, adsorption, charge neutralization and bridging. Charge neutralization is thought to be the major mechanism when the coagulant is oppositely charged as compared to the constituents under treatment. Nevertheless, under conditions for coagulants that present negative surface charge, the predominant mechanism governing the aggregation of the constituents by HBaqs is bridging (Duan and Gregory 2003; Zouboulis et al. 2004).

The effectiveness of the bridging mechanism depends on the molecular weight of the coagulant, the charge on the coagulant and the suspended particle, the ionic strength of suspension, and the nature of mixing (Zhang et al. 2010). Having high molecular weight $(>100 \mathrm{kDa})$ do not give much benefits for removal rate by HBaqs. High molecular weight polymer was expected to diffused slowly and subsequently prolong the absorption process.

In general, results showed that the optimum dose for HBaqs to act as coagulant aid with $4,000 \mathrm{mg} / \mathrm{L}$ alum at $\mathrm{pH} 6$ in leachate was $500 \mathrm{mg} / \mathrm{L}$. At this optimum dose, $4,000 \mathrm{mg} / \mathrm{L}$ alum combined with $500 \mathrm{mg} / \mathrm{L}$ HBaqs effectively removed $100 \% \mathrm{Fe}^{3+}, 72 \% \mathrm{SS}$ and $60 \%$ turbidity as compared with the use of $4,000 \mathrm{mg} / \mathrm{L}$ alum alone $(60,45$ and $36 \%$ removals, respectively). However, HBaqs showed a high coagulation activity when act as sole coagulant in removing $54 \%$ of leachate at $\mathrm{pH}$ of 10 in comparison with only about $23 \%$ removal at $4,000 \mathrm{mg} / \mathrm{L}$ alum as sole coagulant. Hence, this indicated that HBaqs could act as sole coagulant at high $\mathrm{pH}$.

\section{Conclusions}

It can be concluded that 4,000 $\mathrm{mg} / \mathrm{L}$ alum combined with $500 \mathrm{mg} / \mathrm{L}$ HBaqs exhibits a synergic effect on $\mathrm{Fe}^{3+}, \mathrm{SS}$, and turbidity removals, and is more advantageous than the use of $4,000 \mathrm{mg} / \mathrm{L}$ alum as sole coagulant. The research has shown a good potential of HBaqs to be used as natural coagulant aid in leachate treatment as alternative to the commonly use polymeric commercial coagulant aid.

Open Access This article is distributed under the terms of the Creative Commons Attribution License which permits any use, distribution, and reproduction in any medium, provided the original author(s) and the source are credited.

\section{References}

Aguilar MI, Saez J, Llorens M, Soler A, Ortuno JF, Meseguer V, Fuentes A (2005) Improvement of coagulation-flocculation process using anionic polyacrylamide as coagulant aid. Chemosphere 58:47-56

Anastasakis K, Kalderis D, Diamadopoulos E (2009) Flocculation behavior of mallow and okra mucilage in treating wastewater. Desalination 249:786-791

APHA, AWWA, WEF (2005) Standard methods for the examination of water and wastewater, 21st edn. American Public Health Association, Washington

Aziz HA, Adlan MN, Mohamed AMD, Raghavan S, Koflly M, Isa M, Abdullah MH (2000) Study on the anionic natural coagulant aid for heavy metals and turbidity removal in water at $\mathrm{pH} 7.5$ and alum concentration $25 \mathrm{mg} / \mathrm{L}-$ laboratory scale. Indian $\mathrm{J}$ Eng Mater Sci 7(4):195-199

Aziz HA, Alias S, Adlan MN, Asaari FAH, Zahari MS (2007) Colour removal from landfill leachate by coagulation and flocculation processes. Bioresour Technol 98:218-220

Beltrán-Heredia J, Sánchez-Martín J (2009) Removing heavy metals from polluted surface water with a tannin-based flocculant agent. J Hazard Mater 165:1215-1218

Cheng WP, Chi FH (2002) A study of coagulation mechanism of polyferric sulfate reacting with humic acid using fluorescencequenching method. Water Res 36:4583-4591

Cheng WP, Chi FH, Yu RF (2004) Effect of phosphate on removal of humic substances by aluminum sulfate coagulant. J Colloid Interface Sci 272:153-157

Duan J, Gregory J (2003) Coagulation by hydrolyzing metal salts. Adv Colloid Interface Sci 100-102:475-502

Environmental Quality Act 1974 (2010). http://www.doe.gov.my/en/ content/environmental-quality-act-1974. Accessed 15 July 2010

Ersoy B (2005) Effect of pH and polymer charge density on settling rate and turbidity of natural stone suspensions. Int $\mathrm{J}$ Miner Process 75:207-216

Ghafari S, Aziz HA, Bashir MJK (2010) The use poly-aluminum chloride and alum for the treatment of partially stabilized leachate: a comparative study. Desalination 257:110-116

Hanafiah MAKM, Ngah WSW, Zakaria H, Ibrahim SC (2007) Batch study of liquid-phase adsorption of lead ions using Lalang (Imperata cylindrica) leaf powder. J Biol Sci 7:22-230

Henderson JM, Wheatley AD (1987) Factors effecting a loss of flocculation activity of polyacrylamide solutions-shear degradation, cation complexation and solutions aging. J Appl Polym Sci 33:669-684

Jarvis P, Jefferson B, Parsons SA (2004) Characterising natural organic matter flocs. Water Sci Technol 4(4):79-87

Jarvis P, Jefferson B, Parsons SA (2005) Measuring floc structural characteristics. Rev Environ Sci Biotechnol 4:1-18

Kam S-K, Gregory J (2001) The interaction of humic substances with cationic polyelectrolytes. Water Res 35(15):3557-3566

Lee W, Westerhoff P (2006) Dissolved organic nitrogen removal during water treatment by aluminum sulfate and cationic polymer coagulation. Water Res 40:3767-3774

Li WW, Zhou WZ, Zhang YZ, Wang J, Zhu XB (2008) Flocculation behavior and mechanism of an exopolysaccharide from the deepsea psychrophilic bacterium Pseudoalteromonas sp. SM9913. Bioresour Technol 99:6893-6899

Okuda T, Baes AU, Nishijima W, Okada M (2001a) Isolation and characterization of coagulant extracted from Moringa oleifera seed by salt solution. Water Res 35:405-410

Okuda T, Baes AU, Nishijima W, Okada M (2001b) Coagulation mechanism of salt solution: extracted active component in Moringa oleifera seeds. Wat Res 35:830-834 
Prasertsan P, Dermlim W, Doelle H, Kennedy JF (2006) Screening, characterization and flocculating property of carbohydrate polymer from newly isolated Enterobacter cloacae WD7. Carbohydr Polym 66:289-297

Šćiban M, Klašnja M, Antov M, Škrbić B (2009) Removal of water turbidity by natural coagulants obtained from chestnut and acorn. Bioresour Technol 100:6639-6643
Zhang Z, Xia S, Zhao J, Zhang J (2010) Characterization and flocculation mechanism of high efficiency microbial flocculant TJ-F1 from Proteus mirabilis. Colloids Surf B Biointerfaces 75:247-251

Zouboulis AI, Chai XL, Katsoyiannis IA (2004) The application of the bioflocculant for the removal of humic acids from stabilized landfill leachates. J Environ Manage 70:35-41 